\title{
ANALISIS PERUBAHAN PENUTUPAN LAHAN MANGROVE DI KABUPATEN SERAM BAGIAN BARAT MALUKU
}

\author{
Debby V Pattimahu \\ Jurusan Kehutanan Fakultas Pertanian Universitas Pattimura Ambon \\ Jl. Ir. M. Putuhena, Kampus Poka - 97237 Ambon \\ Penulis Korespondensi Email : debby_pattimahu@yahoo.com
}

Diterima : 4 Juni 2016

Disetujuai : 11 Agustus 2016

\begin{abstract}
Intisari
Analisis Perubahan Tutupan Lahan Mangrove di Kabupaten Seram bagian Barat, Propinsi Maluku. Tujuan dari penelitian ini adalah menganalisis perubahan tutupan lahan mangrove di Kabupaten Seram Bagian Barat Propinsi Maluku. Hasil analisis Landsat 7 ETM + dan overlay peta menunjukkan bahwa hutan mangrove di kabupaten Seram Bagian Barat dalam dua tahun mengalami penurunan sekitar 174 ha atau 7,4\%. Hasil analisis juga menunjukan bahwa perubahan tutupan lahan mangrove disebabkan oleh eksploitasi hutan bakau oleh masyarakat setempat, perluasan pemukiman, perkebunan dan tingkat pendidikan masyarakat yang rendah menjadi kendala utama dalam meningkatkan pengetahuan mereka tentang pentingnya ekosistem hutan mangrove. Di samping itu tingkat pendidikan yang rendah berdampak terhadap persepsi masyarakat tentang pentingnya konservasi mangrove dalam pemanfaatannya untuk memenuhi kebutuhan masyarakat.
\end{abstract}

Kata kunci: Ekosistem, Hutan mangrove, Kabupaten Seram Bagian Barat, Perubahan tutupan lahan

\section{Abstract}

Analysis of Land Cover Change Mangrove in Western Part of Seram Regency, Maluku. The aim of this study is analyzing land cover change of mangrove in Western Part of Seram Regency Maluku. Results of image Landsat 7 $E T M+$ overlay indicated that mangrove forests area in Western Part of Seram in two years was decreased approximately 174 ha or $7.4 \%$. This affected mangrove land cover changes, because of mangrove exploitation by local communities, expansion of settlements, plantations and clearing The low public education level study sites became the main obstacle in improving their knowledge about the importance of mangrove forest

ecosystems. Low education level impacted public perception on the lack of mangrove conservation importance so that they used mangrove forests to fullfill their needs.

Keywords :Ecosystem, Land cover change, Mangrove forest, Western of Seram district

\section{PENDAHULUAN}

Ekosistem mangrove di Indonesia mempunyai keanekaragaman hayati tertinggi di dunia dengan jumlah species 89 jenis yang terdiri dari 35 species pohon, 5 jenis terna, 9 jenis perdu, 9 jenis liana, 29 jenis epifit dan 2 jenis parasit (Soemadihardjo dkk, 1993 dalam Kusmana, 2003). Beberapa jenis pohon mangrove yang umum dijumpai di wilayah pesisir Indonesia adalah Bakau (Rhizopora spp ), Api-api (Avicennia spp), Pedada (Sonneratia spp.), Tancang (Bruguiera spp.), Nyirih (Xylocarpus spp.), Tengar (Ceriops spp.) dan Buta-buta (Excoceria spp.). Spesies pohon tersebut berasosiasi dengan ribuan spesies mamalia, burung, ikan dan invertebrata (IUCN, 1993).

Pemanfaatan ekosistem mangrove terus meningkat pada dekade akhir kini, bukan saja dari segi pemanfaatan lahannya tetapi juga dari segi pemanfaatan tegakan mangrovenya, baik secara tradisional maupun secara komersial. Tekanan terhadap ekosistem mangrove sangat besar dan terus meningkat, sehingga berimplikasi terhadap perubahan areal dan tata guna lahan. Secara umum berdasarkan data Citra Landsat 7 ETM+ tahun 2001 di Kabupaten Seram Bagian Barat, luas hutan mangrove 3.823,30 ha, daerah penyebarannya meliputi Kotania (Teluk Kotania), Kaibobu, Piru, Aryate (Teluk Piru), Rumahkay (Selat Seram), Buano dan Pulau Kelang. Tupan (2000) menyatakan bahwa sesuai data Citra Landsat-5 1993 luas hutan mangrove di Teluk Kotania sampai Pelita Jaya adalah 1171,5 ha dan pada tahun 1997 luasannya berubah menjadi 1146,7 ha. Hal ini berarti bahwa dalam kurun waktu empat tahun terjadi pengurangan luas area hutan mangrove secara drastis, yaitu sekitar 6,2 ha/tahun. Selanjutnya Balai Pemetaan Hutan Ambon (2007) menyatakan bahwa luas hutan mangrove di Teluk Kotania sampai tahun 2001 luasannya berubah menjadi 553,84 ha 
sesuai data Citra Landsat 7 ETM+.

Berdasarkan data Citra Landsat 7 ETM+, kondisi hutan mangrove dengan penyusutan luas yang besar terjadi di Teluk Kotania, Teluk Piru dan Selat Seram. Berkurangnya area hutan mangrove disebabkan karena beberapa tahun terakhir pertumbuhan penduduk di wilayah pesisir ini relatif tinggi. Di samping itu pola pemanfaatan hutan mangrove yang selama ini dilakukan masyarakat di Kabupaten Seram Bagian Barat berbasis pada kepentingan individu atau kelompok tertentu seperti peneba-ngan hutan mangrove untuk bahan bangunan, mangrove untuk bahan bangunan, kayu bakar, tiang pancang dalam pembudidayaan biota laut, kulit kayu untuk bahan penyamak jaring; konversi hutan mangrove menjadi areal budidaya tambak, pertanian dan permukiman. Penelitian Ini bertuijuan untuk menganalisis perubahan penutupan lahan mangrove di Kabupaten Seram Bagian Barat Maluku. hutan mangrove menjadi areal budidaya tambak, pertanian dan permuki-man. Penelitian ini diharapkan dapat memberi-kan kontribusi pemikiran dan sebagai bahan informasi dan referensi bagi stakeholder dalam pengelolaan hutan mangrove berkelanjutan.

\section{METODE PENELITIAN}

\section{Lokasi dan Waktu Penelitian}

Penelitian dilakukan di Kabupaten Seram Bagian Barat (SBB), yang terdiri dari empat kecamatan, yaitu Kecamatan Seram Barat, Kecamatan Huamual Belakang, Kecamatan Taniwel dan Kecamatan Piru. Batas koordinat wilayah Pulau Seram mulai dari $127^{\circ} 28^{\prime} 16,33^{\prime \prime}$ sampai 128 ' 50'31,59" Bujur Timur dan $2^{\circ} 49^{\prime} 46,93$ ” sampai $3^{\circ} 34^{\prime} 15,45^{\prime \prime}$ Lintang Selatan. Penentuan stasiun pengamatan dilakukan berdasarkan data Citra Satelit landsat 7 ETM+ akuisisi 2004 dan peta penyebaran dan kerusakan mangrove. Stasiun pengamatan terdiri dari empat stasiun dengan luasan mangrove yang berbeda, yaitu Stasiun I : Teluk Piru, Kecamatan Seram Barat (751,66 Ha); Stasiun II dan III : Teluk Kotania dan Pelita Jaya, Kecamatan Seram Barat $(553,84 \mathrm{Ha})$; Stasiun IV: Selat Seram, Kecamatan Piru $(187,49 \mathrm{Ha})$. Waktu penelitian dilaksana-kan selama 6 bulan mulai bulan Oktober 2009 sampai Maret 2010.

\section{Alat dan Bahan Penelitian}

Peralatan yang digunakan dalam penelitian ini, antara lain : seperangkat komputer, perangkat lunak ERDAS Imagine 9.1 digunakan untuk pengolahan data citra secara digital dan ArcView ver 3.3 digunakan untuk overlay citra dan tampilan citra dan peralatan lapangan berupa: Global Positioning System (GPS), kompas, meteran dan tali sheet.

Bahan-bahan utama yang digunakan dalam penelitian adalah : Citra Landsat $7 \mathrm{ETM}^{+}$wilayah Kabupaten Seram Bagian Barat tahun 2003 dan tahun 2005; peta dasar Kabupaten Seram Bagian Barat berupa peta topografi, peta land use, peta sebaran dan kerusakan mangrove; Peta Rupa Bumi Indonesia ( $1: 250.000)$ daerah Maluku.

\section{Analisis Data \\ Analisis Perubahan Penutupan Lahan (Land cover)}

Analisis perubahan penutupan lahan (land cover) hutan mangrove dilakukan dengan metode SIG yaitu dengan overlay terhadap dua citra yang telah diolah, sehingga dapat diketahui perubahan luasan obyek yang diamati. Dengan cara ini dapat diketahui luas perubahan penutupan lahan yang terjadi pada ekosistem hutan mangrove. Adapun tahapan-tahapannya sebagai berikut :

1. Persiapan data Citra Landsat 7 ETM+ tahun 2001 dan 2005.

2 . Pemulihan Citra ( Image restoration ) (Lillesand dan Kiefer, 1990). Pemulihan berfungsi untuk memulihkan citra yang mengalami distorsi atau rusak, ke arah gambaran yang sebenarnya atau ke arah yang sesuai dengan keadaan yang sebenarnya di bumi, sehingga citra dapat bermanfaat untuk analisis. Langkah yang dilakukan yaitu dengan menggunakan koreksi geometrik. Koreksi geometrik dilakukan dengan menggunakan metode berdasarkan titik kontrol lapangan (GCP) dengan tahapan sebagai berikut :

a. Pemilihan titik kontrol lapangan (GCP) secara tersebar merata di seluruh citra pada obyek yang relatif permanen dan tidak berubah dalam kurun waktu pendek

b. Perhitungan root mean squared error (RMSE) setelah GCP terpilih. Sebaiknya RMSE bernilai kurang dari 0,5 piksel.

c. Resampling, yaitu proses penerapan alih ragam geometrik terhadap data asli.

3. Pemotongan Citra ( image cropping ) Pemotongan citra dilakukan untuk membatasi citra sesuai dengan lokasi yang akan diteliti. Pemotongan dilakukan setelah citra tersebut dikoreksi.

4. Penajaman Citra (image enhancement) 
(Lillesand dan Kiefer, 1990). Penajaman citra dilakukan untuk menguatkan tampakan kontras diantara kenampakan pada citra, sehingga meningkatkan jumlah informasi yang dapat diinterpretasikan secara visual pada citra. False colour composite (FCC) merupakan penajaman dengan menggunakan warna dalam meningkatkan kontras citra dengan menggabungkan tiga warna primer, yaitu biru, hijau dan merah. Pada citra Landsat, FCC yang digunakan untuk mendeteksi atau membedakan secara visual hutan mangrove dengan hutan darat adalah citra komposit warna semu RGB kombinasi band 453 .

5. Klasifikasi Citra (image classification) (Lillesand dan Kiefer, 1990). Dalam penelitian ini klasifikasi yang digunakan adalah klasifikasi tidak terbimbing (unsupervised classification). Klasifikasi tidak terbimbing merupakan klasifikasi tanpa menggunakan daerah contoh yang ditetap-kan. Klasifikasi dilakukan berdasarkan nilai piksel secara statistik dan kelas yang diperoleh merupakan kelas yang abstrak. Jumlah kelas citra Landsat tahun 2003 sama dengan jumlah kelas tahun 2005. Citra klasifikasi yang sebelumnya memiliki format data raster (*. ers) dikonversi menjadi format data vektor (*.shp) pada Arc View 3.3 untuk mengetahui jumlah luasan penutupan lahan.

6. Setelah format diseragamkan citra dianalisis dengan menggunakan Sistem Informasi Geografi (GIS) dengan software Arc view 3.3. Proses overlay dilakukan dengan mengga-bungkan kedua citra Landsat dan hasilnya dapat digunakan untuk mengetahui peruba-han penutupan lahan (land cover) hutan mangrove.

\section{HASIL DAN PEMBAHASAN}

\section{Perubahan Penutupan Lahan (Land cover)}

Perubahan lahan dapat dideteksi dengan melakukan pendekatan spasial menggunakan metoda perbandingan citra hasil klasifikasi antara dua citra yang direkam dalam dua waktu yang berbeda. Berdasarkan hasil klasifikasi citra Landsat 7 ETM + liputan tanggal 20 Maret 2003 dan citra Landsat 7 ETM + liputan tanggal 19 Oktober 2005 diperoleh luasan dari penutupan lahan mangrove serta perubahannya pada rentang waktu 2 tahun di Kabupaten Seram Bagian

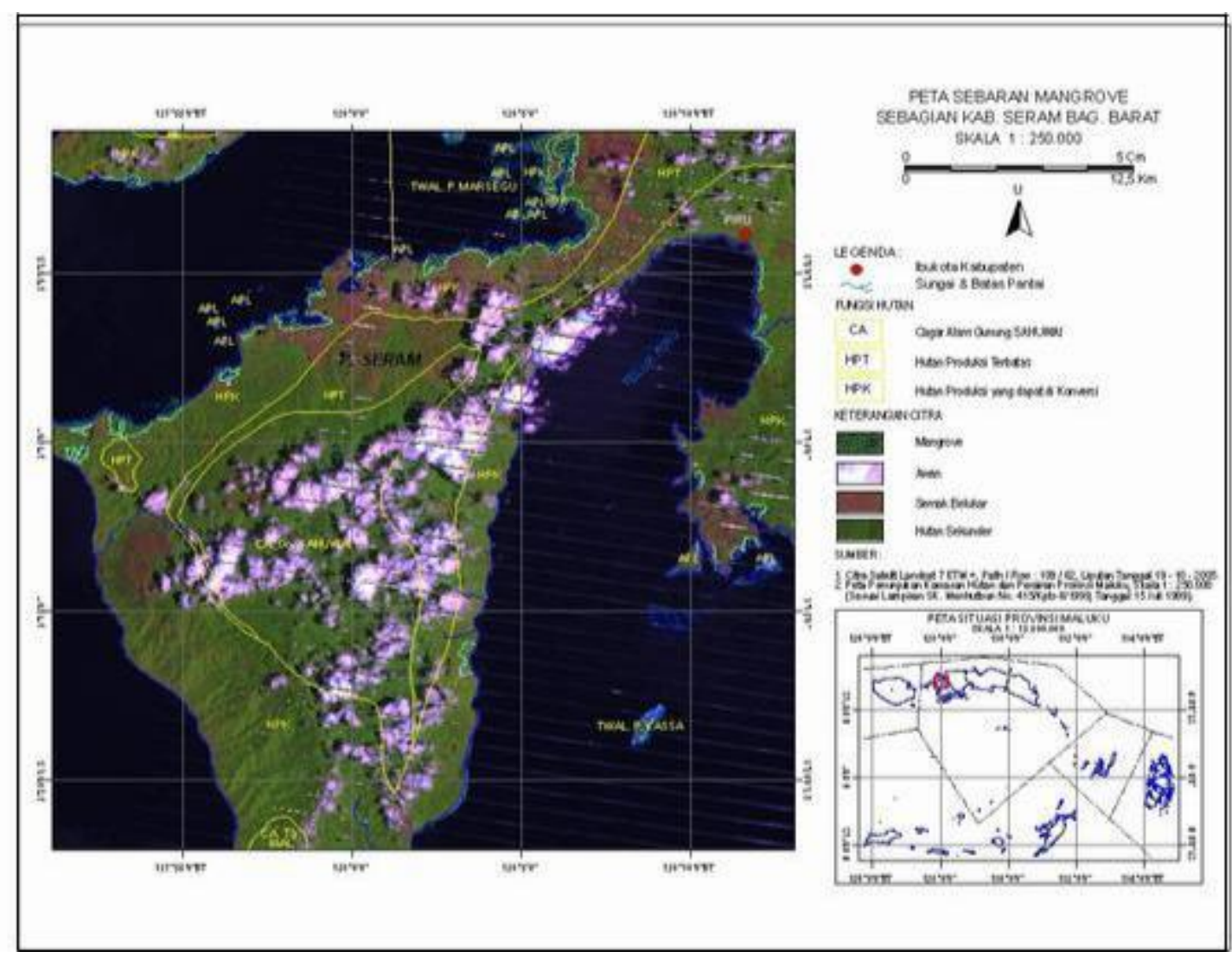

Gambar 1. Peta Penyebaran Hutan Mangrove di Sebagian

Kabupaten Seram Bagian Barat 
Barat. Analisis perubahan penutupan lahan yang didasarkan pada overlay data citra Landsat 7 ETM + tahun 2003 dan tahun 2005 menunjukkan perbedaan penutupan lahan mangrove di Kabupaten Seram Bagian Barat, dimana pada tahun 2003 luasan lahan mangrove sebesar 2363,3 Ha, sedangkan tahun 2005 luasan lahan mangrove menjadi 2189,3 Ha (Gambar 1-5).

Luasan hutan mangrove di wilayah Kabupaten Seram Bagian Barat dalam waktu dua tahun terjadi penyusutan lahan mangrove sebesar $174 \mathrm{Ha}$ atau sekitar 7,4 \%, hal ini berdampak pada perubahan penutupan lahan mangrove, karena adanya eksploitasi mangrove oleh masyarakat lokal yang tidak terkendali, perluasan permukiman, perkebunan dan pembukaan tambak. Namun apabila dibandingkan tingkat penyusutan lahan mangrove dengan luasan mangrove yang ada tidak terlalu besar kerusakannya.

Dari hasil citra landsat, penyusutan lahan mangrove terbesar karena eksploitasi mangrove oleh masyarakat sekitar, akibatnya hutan mangrove menjadi rusak. Perkembangan penduduk yang bergerak cepat diikuti dengan kebutuhan hidup yang semakin meningkat, menyebabkan aktifitas manusia memanfaatkan hutan mangrove untuk pemenuhan kebutuhannya, sehingga berdampak pada kerusakan hutan

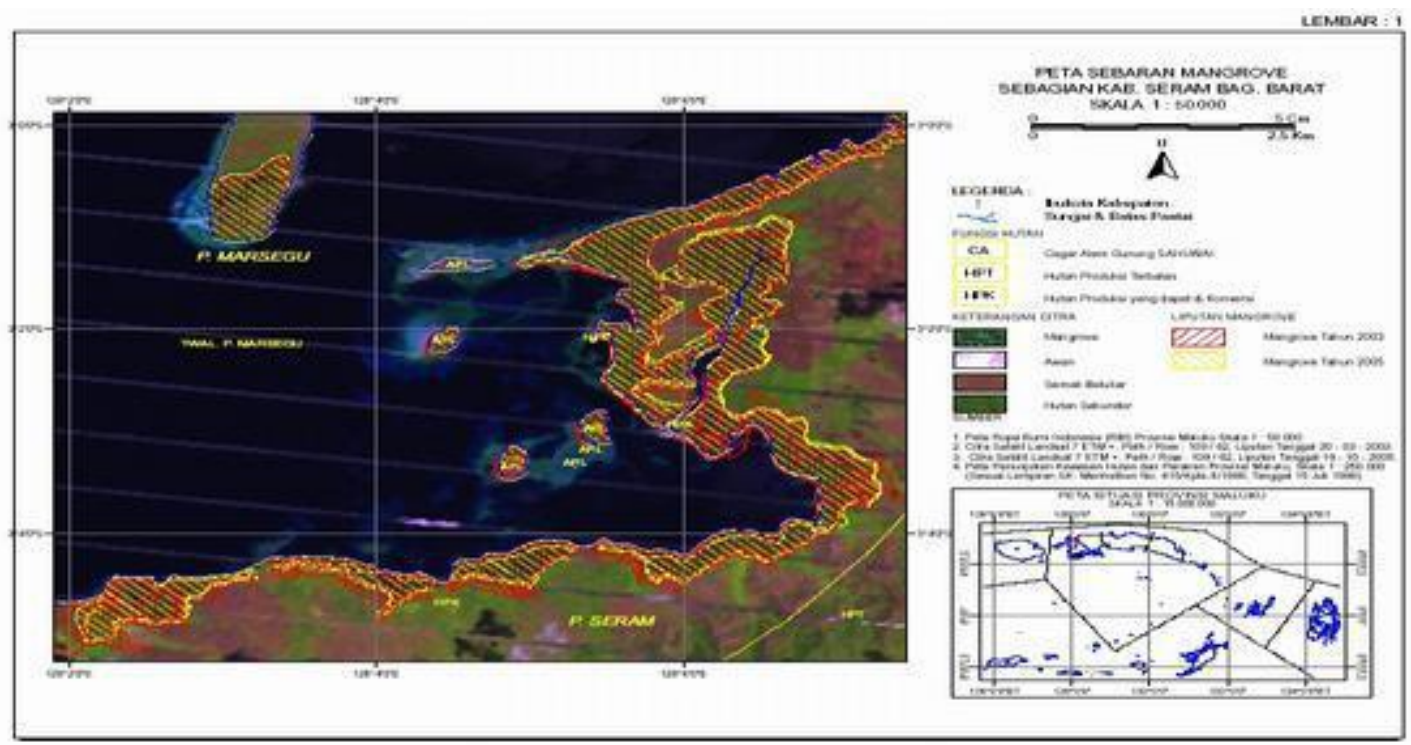

Gambar 2. Peta Penyebaran Hutan Mangrove di Kecamatan Seram Bagian Barat dan Huamual Belakang

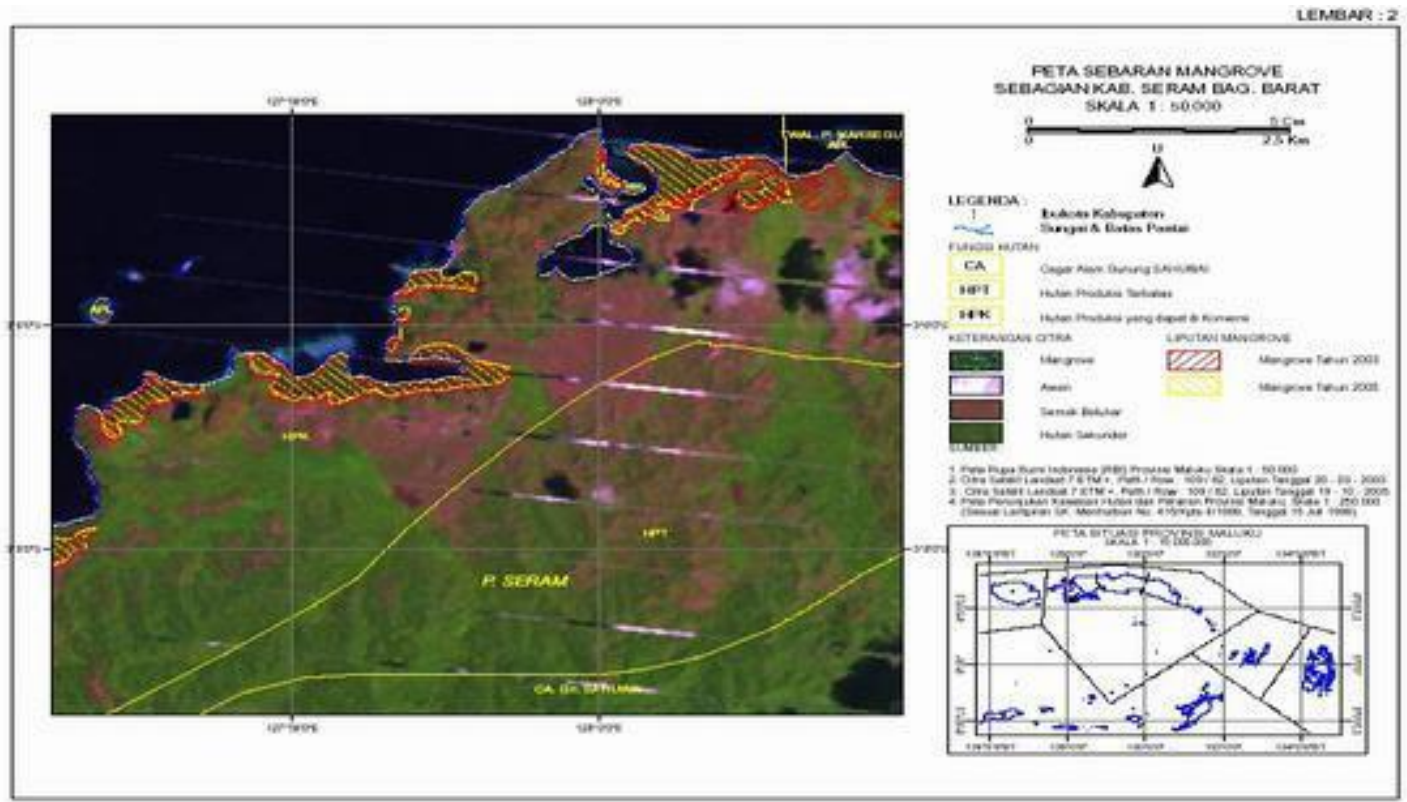

Gambar 3. Peta Penyebaran Hutan Mangrove di Kecamatan

Seram Bagian Barat 


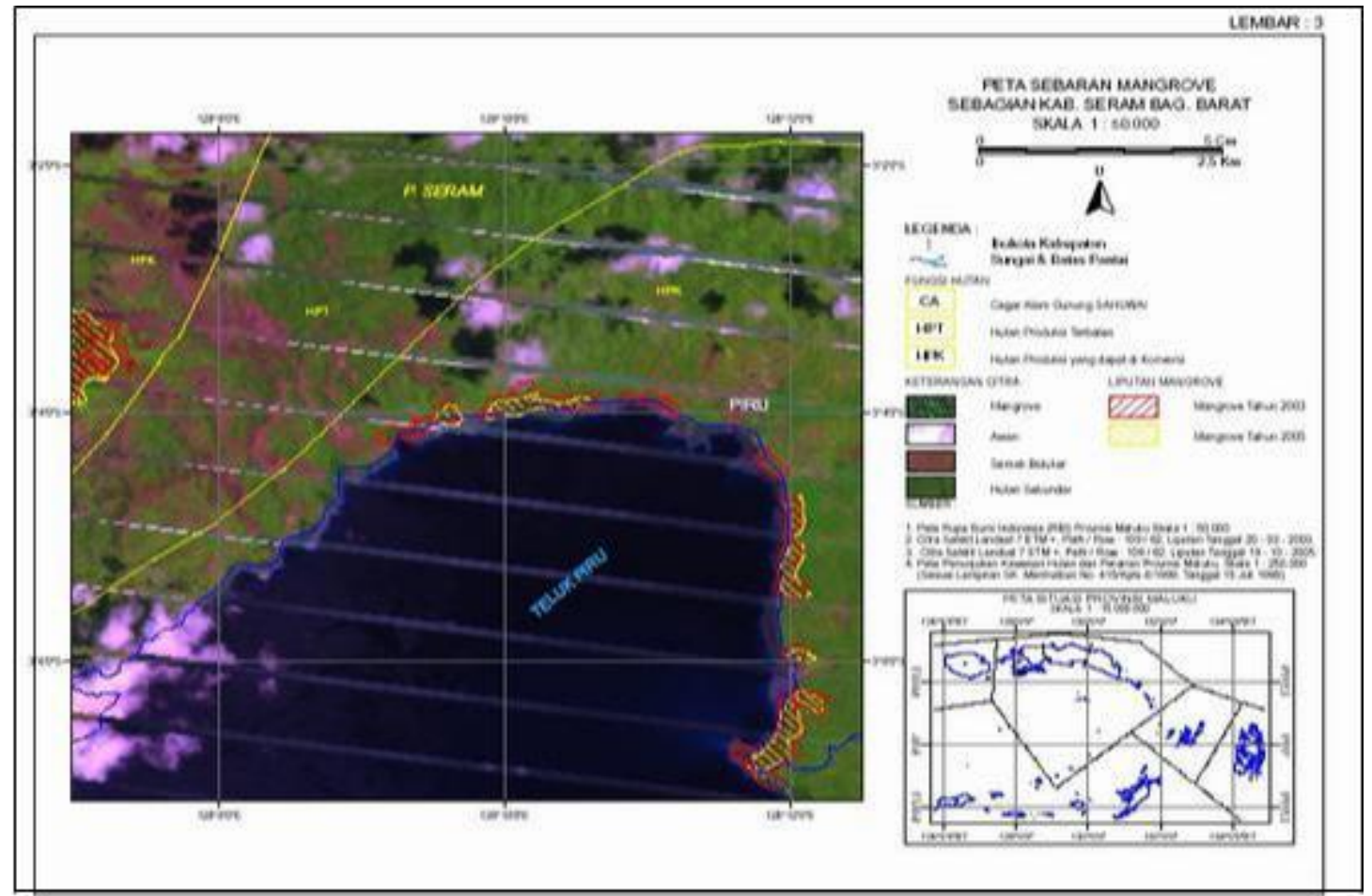

Gambar 4. Peta Penyebaran Hutan Mangrove di Kecamatan

Seram Bagian Barat

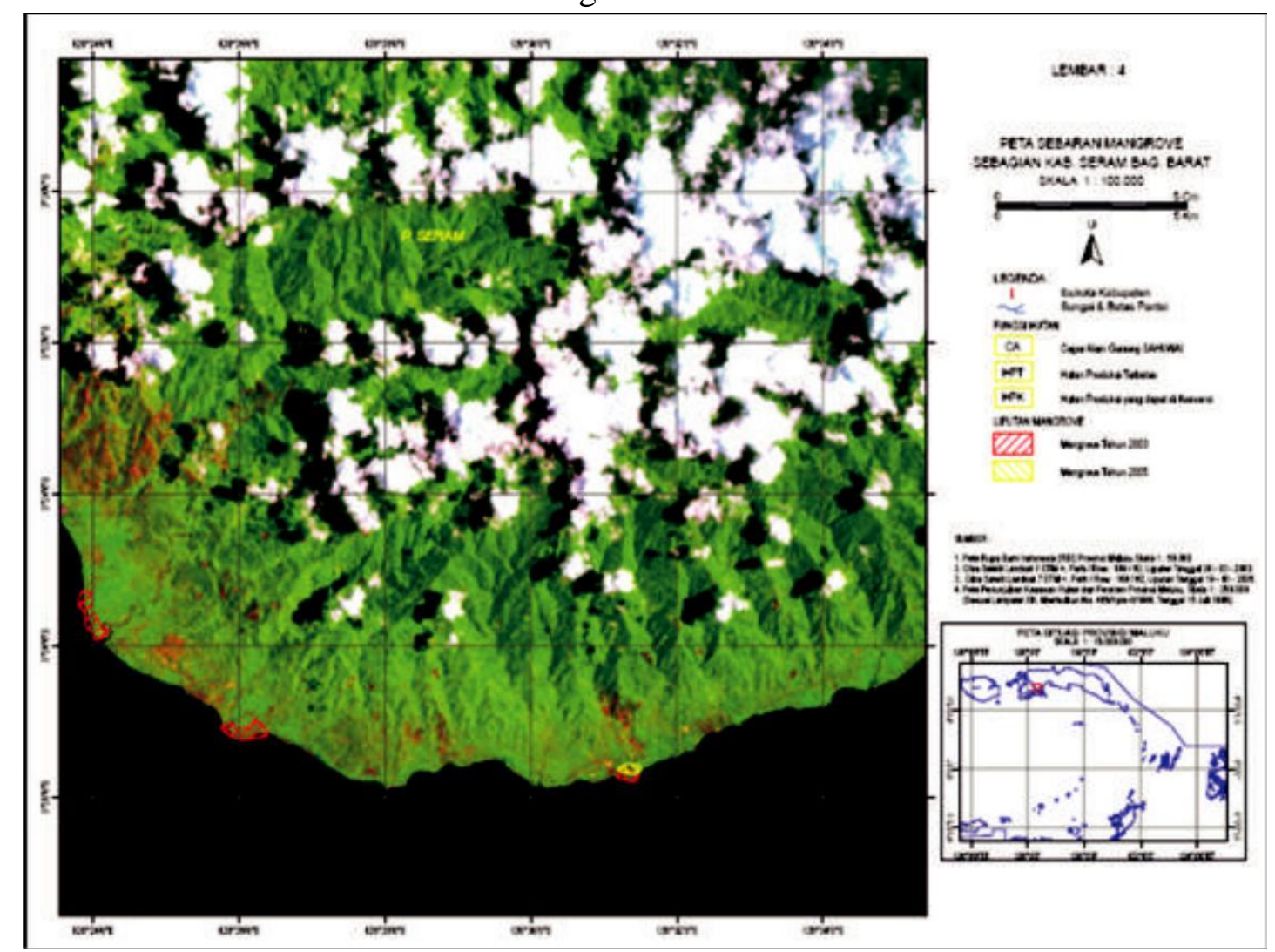

Gambar 5. Peta Penyebaran Hutan Mangrove di Kecamatan Kairatu 
tersebut. Hal ini sesuai dengan pendapat Santoso (2008) yang menyatakan bahwa kerusakan hutan mangrove disebabkan oleh pemanfaatan yang tidak terkontrol, karena ketergantungan masyarakat yang menempati wilayah pesisir sangat tinggi serta konversi hutan mangrove untuk berbagai kepentingan (perkebunan, tambak, pemukiman, kawasan industri, wisata) tanpa mempertimbangkan kelestarian dan fungsinya terhadap lingkungan sekitar.

Kerusakan hutan mangrove dapat mengurangi fungsi mangrove secara fisik, biologi maupun sosial ekonomi. Mengingat hutan mangrove sebagai suatu ekosistem di daerah pasang surut, kehadirannya sangat berpengaruh terhadap ekosistem-ekosistem lain di daerah tersebut. Pada daerah ini akan terdapat ekosistem terumbu karang, ekosistem padang lamun, dan ekosistem estuari yang saling berpengaruh antara ekosistem yang satu dengan lainnya. Dengan demikian, terjadinya kerusakan/gangguan pada ekosistem hutan mangrove tentu saja akan mengganggu keseimbangan ekosistem yang lain dan secara langsung maupun tidak langsung dapat mengganggu kehidupan mahkluk hidup lainnya. Disamping itu kerusakan hutan mangrove dapat pendapatan masyarakat pesisir khususnya para nelayan, karena kehadiran hutan mangrove ini merupakan salah satu faktor penentu pada kelimpahan ikan, udang, kepiting atau berbagai biota laut lainnya. Kerusakan-kerusakan tersebut secara umum juga akan sangat berpengaruh pada perubahan iklim, terutama keselamatan penduduk di sepanjang pantai atau pesisir, karena potensi kenaikan permukaan laut akibat perubahan iklim akan mengancam kawasan pesisir.

\section{KESIMPULAN}

Hutan mangrove di Kabupaten Seram Bagian Barat Maluku dalam kurun waktu 2 tahun (2003 - 2005) telah mengalami penyusutan lahan sebesar $174 \mathrm{Ha}$ atau sekitar 7,4\%, hal ini berdampak pada perubahan penutupan lahan mangrove, karena adanya eksploitasi mangrove oleh masyarakat lokal yang tidak terkendali, perluasan permukiman, perkebunan dan pembukaan tambak. Kondisi ini akan menekan keberadaan ekosistem mangrove. Oleh karena itu kondisi masyarakat yang tinggal di sekitar areal mangrove merupakan masalah substansial dalam usaha menyelamatkan areal mangrove.

\section{DAFTAR PUSTAKA}

IUCN. 1993. Oils and gas exploration and production in mangrove areas : Guidelines for Environmental Protection. IUCN, Island - Switzerland.

Kusmana, 2003. Teknik Rehabilitasi Mangrove. Fakultas Kehutanan IPB. IPB Press. Bogor.

Lillesand ,T. M dan R . W. Kiefer. 1990 . Penginderaan jauh dan interpretasi citra ( $D$ i Ind one si a k a nole h D u lbahri, P.Suharsono, Hartono dan Suharyadi) Gajah Mada University Press. Yogyakarta.

Santoso, U. 2008. Hutan mangrove, permasalahan dan solusinya. Jurnal Pengembangan Peternakantropis. 3 A p ri 1200 8 . http://www.uripsantoso.com/hutan mang-rove, permasalahan dan solusinya/

Tupan, C. 2000. Kondisi, potensi dan pemanfaatan ekosistem mangrove di Teluk Pelita Jaya Seram Barat, Maluku. Tesis (tidak dipublikasikan) Program Pascasarjana IPB. Bogor 